DOI 10.37882/2223-2982.2021.06-2.23

\title{
ТЕХНОЛОГИЧЕСКИЕ ПРИЕМЫ В МОДЕРНИЗАЦИИ РАБОТЫ ПЕДАГОГА
}

\section{TECHNOLOGICAL METHODS IN THE MODERNIZATION OF THE TEACHER'S WORK}

\section{Skopa}

Summary: The article discusses innovative pedagogical technologies as a means of improving the activities of a teacher. With the help of modern innovative technologies, it is possible to achieve an effective result in improving the qualities of a person in the process of mastering knowledge, skills and abilities. In the context of the synthesis of sciences and the process of cognition, the concept of "innovative technologies" is systematically presented as the basis for improving the professional activity of a teacher. In the context of the practical implementation of the tasks of updating the content of education, the organization of systematic work to improve the professional competence of teachers, the introduction of modern innovations into the educational process is acquiring great importance.

Keywords: teacher, innovative technologies, teaching, didactics, teaching methods.

\author{
Скопа Виталий Александрович \\ Д.и.н., профессор, Алтайский государственный \\ педагогический университет, г. Барнаул \\ sverhtitan@rambler.ru
}

Аннотация: В статье рассматриваются инновационные педагогические технологии как средство совершенствования деятельности педагога. С помощью современных инновационных технологий обеспечивается возможность достижения эффективного результата в совершенствовании качеств личности в процессе усвоения знаний, умений и навыков. В условиях синтеза наук и процесса познания системно представляется понятие «инновационные технологии», как основа совершенствования профессиональной деятельности педагога. В условиях практической реализации задач обновления содержания образования важное значение приобретает организация системной работы по повышению профессиональной компетентности педагогов, внедрение в учебно-воспитательный процесс современных инноваций.

Ключевые слова: педагог, инновационные технологии, обучение, дидактика, методика преподавания. роцесс модернизации российского образовательного пространства, совершенствование профессиональной компетентности современного педагога невозможны без внедрения новых педагогических приемов, техники, которые в своей совокупности могут не только обеспечат доступность и эффективность процесса образования, но и подготовят молодежь к жизнедеятельности в современном цифровом обществе. Именно инновационные педагогические технологии являются важнейшим ресурсом в процессе подготовки современного педагога в условиях модернизации.

Инновации в системе образования обусловливают цивилизационное совершенство человечества, оказывают воздействие на профессиональный рост, независимо: большой это город или отдаленное сельское поселение. Использование новейших средств жизнедеятельности кардинально меняет характер бытия человека. На современном этапе реформирования образования в РФ важнейшими задачами являются подготовка образованной, творческой личности и формирования в ней компетенций для эффективной жизнедеятельности и профессионального функционирования. Для решения этой проблемы необходимо психолого-педагогическое обоснование содержательной основы учебно-методического и воспитательного процессов. В процессе по- иска новой образовательной парадигмы широкое распространение получают различные виды и формы профессионального образования, которые являются ведущим условием всестороннего развития личности и ее гармонии в обществе.

Заявленная проблема имеет теоретическую и практическую значимость, что подчеркивается попытками всестороннего переосмысления ученых. Разработке теоретических основ педагогических технологий посвящены исследования И.П. Подласого, М.В. Кларина, А.А. Дубасенюк, В.А. Сластенина [4, 6, 7, 10, 11, 13] Теоретические и практические аспекты применения интерактивных методов обучения отражено в работах Х. Браун, В.П. Беспалько, В.И. Загвязинского, А.И. Пометун [2, 3, 5, 12].

С помощью современных инновационных технологий обеспечивается объективная возможность достижения эффективного результата в совершенствовании качеств личности в процессе получения новых знаний, расширения умений и навыков. Однако, несмотря на наличие в научном дискурсе огромного количества работ по проблемам новейших инновационных педтехнологий и особенностей их внедрения в практику преподавания учебных дисциплин, нерешенной остается про- 
блема содержательного наполнения самой дефиниции «инновационные технологии обучения» [1].

Исходя из массива изученных работ целью данной статьи является раскрыть сущностное понятие, особенности внедрения и реализацию инновационных технологий в процесс обучения.

Современная действительность бросает вызов молодым специалистам с позиции нестандартного мышления и креативного подхода к решению стоящих или возникающих проблем, при том существенно возрастает потребность в творческой активности профессионала, его развитом технологическом мышлении, где важнейшими компонентами являются: умение оценивать и наличие рационального подхода к использованию новых технологических приемов. Исходя из этого, всецелостность решения этой проблемы зависит от содержательного компонента и технологий процесса обучения специалистов.

Необходимость внесения инновационных изменений в систему образования обусловлена тем, что сегодня от руководителей и работников нужны не только глубокие знания, но и умение в меняющихся ситуациях их приобретать самостоятельно, а также использовать для проектирования собственной деятельности и деятельности подчиненных [14].

Исходя из устоявшихся научно-педагогических концепций в практике образования выделяют следующую совокупность технологий: традиционные, интерактивные, инновационные, информационные, коммуникативные, гуманитарные [5]. В условиях синтеза наук и процесса познания можно системно представить понятие «инновационные технологии», как основу совершенствования профессиональной деятельности педагога. Данная проблема разноаспектно разрабатывалась иностранными и отечественными учеными. Так, И.П. Подласый отмечает, что инновации - это концептуальные идеи, и процессы, и средства, и результаты, взятые в качестве качественного совершенствования педагогической системы [11]. Сластенин В.А. считает инновации комплексным процессом создания, распространения и использования нового практического средства в области техники, технологии, педагогики, научных исследований [13]. Сущностным признаком инновации А.А. Дубасенюк считает ее способность существенно влиять на общий уровень деятельности учителя, расширять поле образовательной среды в учебном заведении, регионе [4]. Кларин М.В. отмечает, что по своему основному содержанием понятия «инновация» относится не только к созданию и распространению новшеств, а к изменениям в способах деятельности, стилях мышления [7]. Пометун А.И. отмечают, что «Интерактивные технологии обучения - это такая организация учебного процесса, которая основана на взаимодействии всех участников процесса учебного познания» [12]. Исходя из выше определенных концептуальных идей к пониманию понятия «инновационные технологии» можно определить, что инновации в образовании - это системный процесс создания, внедрения и распространение в образовательной практике новых идей, средств, педагогических и управленческих технологий, в результате которых повышаются показатели достижений структурных компонентов образования [5]. Рассматривая понятие далее, можно с уверенностью констатировать, что инновационные технологии - объективно новые технологии как результат педагогического творчества. Интересным представляется позиция Ковальчука В., который выделяет в образовании следующие инновационные технологии и методы обучения: информационные технологии; работа в команде (коучинг); игра; проблемное обучение; контекстное обучение; обучение на основе опыта (эмпирическое обучение); тренинг; индивидуальное обучение; междисциплинарное обучение; проектная деятельность; опережающая самостоятельная; коммуникативные технологии [8].

На основе анализа научной литературы можно классифицировать инновационные образовательные технологии по группам более укрупненно, что в дальнейшем позволит это системно представить, как целостные категории. Нужно отметить, что это не только технологии обучения, но и оценивания, контроля, психолого-педагогической рефлексии. Фактически, это все то, что комплексно используется в современном процессе обучения, и порой очень сложно вычленить отдельный технологический прием в отрыве от другого.

А) Цифровые технологии (цифровизация). Данные технологические приемы представляют собой синтез информационных технологий и любой предметной области. Процесс цифровизации существенно меняет обыденное сознание, тем самым формируя новые идейные установки, взгляды, позиции. Особенно это касается тех областей знания, в которых происходят или могут произойти глубинные перестройки, требующие цифровизации. Эти технологические приемы способствуют существенной мотивации в обучении и, как следствие повышают качественную основу результатов обучения. Немаловажным является и рост информационной культуры как важнейший элемент общекультурного развития индивида. На сегодняшний день цифровизация приобрела неотъемлемость от всего процесса познания, в том числе и обучения. Она является имманентной категорией и фактически неотделимой от современной системы образования.

Б) Личностно-ориентированные технологии. Данная группа технологических приемов ставит в основу всей образовательной системы субъект образования, где немаловажным будет являться создание комфортных, 
бесконфликтных и безопасных условий для его развития, а также раскрытие его природного потенциала [5]. Нужно отметить, что эти технологии во многом являются основополагающими в образовательном процессе и достаточно легко синтезируют с другими педагогическими приемами. Современное образование ставит целью не только формирование всесторонней и гармонично развитой личности, но и определение личностного «Я», как форму профессионального «Эго», а данные приемы позволяют методично и точечно влиять на акторов рассматриваемого процесса.

В) Технологии управления качеством образования. Данная группа в современном образовательном процессе существенно расширяется и во многом это объясняется необходимостью объективного и беспристрастного оценивания участников в системе образования. Информационно-аналитическая методика позволяет это делать весьма быстро и точно, а полученные результаты в последствии приобретают роль важнейшего инструмента для организации образовательного процесса как сложно организованной системы.

Г) Системный контроль интеллектуального развития (мониторинг успеваемости). Совокупность технологических прием здесь позволяет производить анализ и диагностику качества обучения. Форматы и механизмы могут быть самыми различными: тестирование, контрольно-обобщающий срез, оценка динамики результатов и прочее. Все это в последствии способствует корректировке использования технологических приемов для совершенствования результатов процесса обучения.

Д) Воспитательные технологии. В современной действительности они приобретают все большую значимость и важность. Во многом это то, что формирует гражданскую позицию, умение сказать «да» или «нет». В большинстве своем они реализуются посредством вовлечения субъекта образовательного процесса в участие в культурно-массовые мероприятия, а отчасти представлены как элемент всей системы образования.

Сейчас, в контексте цифровизации образования растут требования к повышению уровня цифровой компетентности педагогов, что позволит им оперативно и адекватно реагировать на все перемены, вызовы действительности. Исходя из этого актуализируется потребность внедрения в образовательный процесс цифровых технологий [9].

В условиях практической реализации задач обновления содержания образования важное значение приобретает организация комплексной работы по повышению профессиональной компетентности педагогов, внедрение в учебно-воспитательный процесс современных инновационных технологий. Практика показывает, что источники саморазвития учебного заведения находятся в творчестве педагогов, их профессиональном мастерстве, осознании ими вопросов, которые стоят перед учебными заведениями. Одним из важнейших факторов, который стимулирует рост профессионального мастерства, помогает рождению собственного педагогического почерка, является целенаправленная работа над единой учебно-научно-методической проблемой - коллективной формой поисковой работы, нацеленной на решение актуальной психолого-педагогической проблемы с целью совершенствования учебно-воспитательного процесса и повышения профессионально-квалификационного уровня педагогических работников.

Обобщая теоретико-практическую основу изученных работ, можно выделить ключевые направления деятельности педагогического коллектива по совершенствованию и разработке новых технологических приемов:

- разработка творческими группами основных положений, рекомендаций, методов, мероприятий, технологий, наиболее эффективных в работе учреждения, каждого педагога в частности;

- выполнение педагогами конкретных научно-исследовательских задач;

- организация взаимного посещения занятий, изучение и выполнение педагогами предложенных методических рекомендаций, что будет порождать новый продукт деятельности;

- обобщение и внедрение в практику работы педагогов перспективного педагогического опыта по данной проблеме;

- совершенствование методики анализа посещенных занятий администрацией заведения, методическим активом;

- организация методических семинаров, лекций, занятий-консультаций для педагогов-экспериментаторов;

- создание банка информации по внедрению проблемы в учебно-воспитательный процесс учреждения;

- выпуск методических бюллетеней из опыта работы над проблемой;

- творческие отчеты лучших педагогов по результатам работы над научно-методической проблемой.

Результатом этой многоплановой работы могут стать методические материалы и рекомендации по планированию деятельности педагогических работников, применения нестандартных форм коллективной и индивидуальной методической работы. Кроме актуальности и перспективности, инновационная деятельность педагогического коллектива может сработать на конкретный конечный результат, ведь в процессе работы над проблемой создаются оптимальные условия для профессионального и методического роста каждого педагогического работника, повышение творческого потенциала 
педагогического коллектива в целом, а в конечном результате - на совершенствование учебно-воспитательного процесса и, как следствие, повышении качества подготовки квалифицированных специалистов.

Таким образом, можно отметить, инновационные технологии в образовательном процессе способствуют повышению качества и эффективности обучения и воспитания личности. Они нацелены на подготовку высоко- квалифицированных специалистов. К тому же инновационные технологии обучения стимулируют активное участие в проблемных ситуациях, которые возникают как перед отдельным педагогом, так и перед учебным заведением. Осознание потребности в них расширяет горизонты дидактических поисков. Поэтому инновационные технологии обучения связаны с творческим поиском на основе имеющегося опыта.

\section{ЛИТЕРАТУРА}

1. Kovalchuk V., Soroka V., Zaika A. Society. Integration. Education. Proceedings of the International Scientific Conference. Volume I. Higher Education. May 22-th 23-th. 2020. P. 481-492.

2. Баун Х. Принципы преподавания. М., 1994. 162 с.

3. Беспалько В.П. Слагаемые педагогической технологии. М., 1989. 274 с.

4. Дубасенюк А.А., Антонова А.Е. Методика преподавания педагогики. Житомир, 2008. 492 с.

5. Загвязинский В.И. Педагогическое творчество учителя. М., 1987. 197 с.

6. К Кларин М. В. Инновации в мировой педагогике: обучение на основе исследования, игры и дискуссии: Анализ зарубежного опыта. Рига, 1995. 254 с.

7. Кларин М.В. Инновации в обучении // Завуч. 2000. № 23-24. С. 8.

8. Ковальчук В.И. Инновационные подходы к организации учебного процесса. М., 2011. 128 с.

9. К Ковальчук В.И., Федотенко С.Р. Инновационные технологии обучения - основа модернизации профессионального образования // Молодой ученый. 2018. № 12. С. 425-429.

10. Подласый И.П. Педагогика: 100 вопросов - 100 ответов. М., 2004. 365 с.

11. Подласый И.П. Педагогические инновации // Начальная школа. 1998. № 12. С. 3-17.

12. Пометун А.И., Пироженко Л. Современный урок. Интерактивные технологии обучения. Киев, 2004. 192. с.

13. Сластенин В.А., Подымова Л.С. Педагогика: Инновационная деятельность. М., 1977. 224 с.

14. Осипов Е.С. Проектная деятельность как инновационная технология в системе профессионального образования // академия педагогических инноваций. 2018. №1. С. 194-199. 